\title{
Bio-Inspired Fabrication of Silver Nanoparticles Using High Altitude Squamulose Lichen Extract and Evaluation of its Antioxidant, Anticandida and Cytotoxic properties
}

S Shanthi

Mother Teresa Women's University

V. Uma Maheshwari Nallal

Mother Teresa Women's University

Krishnan Anand

Faculty of Health Sciences and National Health Laboratory Service, University of the Free State Balasubramani Ravindran

Kyonggi University

Soon Woong Chang

Kyonggi University

Murugesan Chandrasekaran

Sejong University

Zikhona Tywabi-Ngeva

Nelson Mandela University

Pandi Boomi

Alagappa University

S Ravikumar

Alagappa University

Mohd Shahbaaz Shahbaaz

South Ural State University

Magda H Abdellattif

Deanship of Scientific Research, Taif University

M Razia ( $\nabla$ razia.bt@motherteresawomenuniv.ac.in )

Mother Teresa Womens' University https://orcid.org/0000-0002-3410-5236

\section{Research Article}

Keywords: Lichen, C.subradiata, AgNPs, Antioxidant, Anticandida, Anticancer

Posted Date: April 30th, 2021 
DOl: https://doi.org/10.21203/rs.3.rs-467364/v1

License: (c) (1) This work is licensed under a Creative Commons Attribution 4.0 International License. Read Full License 


\section{Abstract}

Bio-inspired nanoparticle synthesis has attracted substantial interest among the scientific society owing to its eco-friendly and non-toxic nature. In the present study, Silver nanoparticles (AgNPs) were synthesized using high altitude squamulose lichen - Cladonia subradiata and characterized using different techniques. The antioxidant and anticandida activity of AgNPs were evaluated using multiple invitro assays. In-silico molecular docking analysis and in-vitro cytotoxic assay was performed to determine the anti-cancer potential of synthesized AgNPs. The results of the spectroscopic studies revealed the successful synthesis of AgNPs and the presence of different functional groups suggesting the involvement of phytocompounds in the reduction and capping of AgNPs. The average size of the AgNPs was $20 \mathrm{~nm}$ and predominantly spherical in shape. AgNPs demonstrated excellent DPPH free radicals scavenging activity with an $\mathrm{IC}_{50}$ value of $7.51 \pm 0.4 \mu \mathrm{g} / \mathrm{mL}$. C.albicans was identified as the most susceptible strain from the anticandida studies. Usnic acid and Pulvinic acid exhibited low binding energies and showed excellent inhibition interaction with EGFR lung cancer protein. The in-vitro cytotoxic results were impressive with an $\mathrm{IC}_{50}$ value of $28.75 \mu \mathrm{g} / \mathrm{mL}$ for $A 549$ lung cancer cells treated with AgNPs. Thus, the study demonstrates the effective and non-toxic synthesis of AgNPs using a less explored lichen extract as a promising anticandida and anticancer agent in the field of nano-medicine.

\subsection{Introduction}

Lung cancer remains as a major health and the socio-economic burden globally [1]. The incidence and mortality rate of lung cancer has increased over the past decade especially affecting the growth of underdeveloped and developing countries [2]. Smoking is regarded as the serious risk factor of lung cancer; nevertheless the incidence of lung cancer in non-smokers is also on the rise [3]. According to the recent report of GLOBOAN, out of the total cancer cases, $11.6 \%$ is contributed by new lung cancer cases and it also accounts for $18.4 \%$ of the total cancer deaths [4]. Over the years, the theranostic development in treating this dreadful disease has been immensely addressed and ground breaking innovations have been reported [5]. Reduction in the rate of smokers and tobacco users has brought down the rate of lung cancer incidence in leading countries such as the United States [6]. Despite the advancements in theranostics, lung cancer remains the leading cause of cancer deaths occurring per year. Pivotal factors that influence the trends of lung cancer are: (i) smoking (ii) gender, (iii) age, (iv) race, (v) geography and (vi) socio-economic status [7]. However conventional lung cancer theranostics such as chemotherapy, radiation therapy and radiation therapy may have helped a few cancer patients to survive, but the reoccurrence rate and poor survival rate are considered to be the limitations of such treatments [8].

Nanotechnology has revolutionized the trends and applications in several fields, especially in the field of medicine [9]. Competent potential to provide rapid and effective detection of oncogenic molecules along with production of novel nanoparticles for the treatment acknowledges them as promising candidates in the field of cancer theranostics [10]. Bio-inspired fabrications of metallic nanoparticles (MNPs) are acclaimed as the safest and simplest method owing to their environment-friendly nature, non-toxicity and feasibility. In this method, bio-active metabolites act as robust reducing and capping agents that 
influence the synthesis of nanoparticles [11]. Microorganisms and plants are considered as the most promising primal matter for the genesis of MNPs due their ability to produce stable and mono-dispersed particles [12]. Plant-based MNPs synthesis has the advantage of being eco-friendly and economic, while microbes-based MNPs synthesis is regarded effective due to their unique enzyme machinery [13]. In fact, bio-inspired fabrication has become a new trend that is preferred by the scientific society to produce MNPs that are non-toxic, well-morphed, amicable in size, reproducible and easily scaled-up [14]. MNPs synthesized through biological methods are bio-compatible and reported to have anticancer and antimicrobial properties. Anti-cancer potential of these MNPs are reported in cancer cell lines such as A549 (human lung cancer) [15], MCF 7 (human breast cancer) [16], HCT-116 (human colon cancer) [17] and Hep2 (human hepatic cancer) [18]. The anti-cancer mechanism is elucidated to be dependent on intracellular reactive oxygen species production and apoptosis via mitochondria-dependent and caspasedependent pathways [19]. Application of biogenic MNPs also includes imaging facilitators, theranostics and sensor designing $[20,21]$.

Lichens are complex symbiotic organisms that are formed from the intimate association between a mycobiont (fungi) and a photobiont (algae or cyanobacteria) [22]. They are regarded as the primary colonizers and inhabitants of terrestrial ecosystems with worldwide distribution regardless of the geographical characteristics [23]. Lichens are a part of traditional medicine owing to their rich phytochemical profile [24]. Unique and novel secondary metabolites have been identified from the thallus or the lichenized stroma [25]. Among the several identified compounds, metabolites belonging to the class of phenols, depsides, depsones, quinones, furans, dibenzofurans and lactones have gained special interest in the field of medicine [26, 27]. Lichens are regarded as pollution indicators [28] and also their extracts are identified to possess vital antibacterial, antifungal, antiviral, antioxidant, antibiotic, antimutagenic, antipyretic and anti-carcinogenic activities [29]. In the present study, Silver nanoparticles (AgNPs) are synthesized in a rapid and affordable approach using the aqueous extract of squamulose lichen - Cladonia subradiata collected from the Kodaikanal hills of Western ghats region, India. For the first time, in-vitro antioxidant activity, in-silico and in-vitro cytotoxic properties of $C$. subradiata mediated AgNPs have been reported.

\subsection{Materials And Methods}

\subsection{Collection and identification of lichen sample}

A brief survey of lichen distribution was carried out at different altitudes covering various agro-climatic zones of Kodaikanal located in Western Ghats of Tamil Nadu, India. Diverse living and non-living substrata were collected along with lichen thalli to examine the nature of attachment. The collected samples were cautiously packed without disturbing the thalli and the substrata of the sample material and transported to the laboratory at the Department of Biotechnology, Mother Teresa Women's University, Kodaikanal. The sample was identified by Lichenolgist Dr.SanjeevNayaka (CSIR-NBRI),Lucknow,India.

\subsection{Preparation of extract}


The identified lichen sample was washed gently washed under running tap water and rinsed with double distilled water. The sample was shade dried for 7 days and grinded to fine powder using a laboratory mixer grinder. $10 \mathrm{~g}$ of the fine sample powder was weighed and dissolved in $100 \mathrm{~mL}$ of various solvents (polar to non-polar). The mixture was agitated using an orbital shaker at room temperature for 72 hours. The mixture was later filtered, evaporated and stored for further use at $4^{\circ} \mathrm{C}[30]$.

\subsection{Phytochemical screening of $C$. subradiata extract}

Methanol, ethanol, acetone, chloroform, aqueous, petroleum ether and hexane extracts were screened for the presence of phytochemicals. The methods of Harborne [31],Brunton [32] ,and Wagner et al., [33] were followed to detect the presence of alkaloids flavonoids, phenols, saponins, tannins and glycosides.

\subsection{GC-MS analysis of $C$. subradiata extract}

Gas chromatography and Mass spectroscopy has been regarded as a "gold standard" for forensic substance identification because it is used to perform a $100 \%$ specific test, which positively identifies the presence of a particular substance. Aqueous extract of $C$. subradiata dissolve in DMSO was analyzed using a GC Clarus 500 PerkinElmer system and gas chromatograph interfaced to a mass spectrometer (GC-MS) instrument employing the following conditions. The column Elite-1 was fused silica capillary column, operating in electron impact mode at $70 \mathrm{eV}$. Helium $(99.999 \%)$ was used as carrier gas at a constant flow of $1 \mathrm{ml} / \mathrm{min}$ and an injection volume of $2 \mathrm{ml}$ was employed (split ratio of 10:1). Injector temperature was $250^{\circ} \mathrm{C}$. Ion source temperature was $280^{\circ} \mathrm{C}$. The oven temperature was programmed from $110^{\circ} \mathrm{C}$ (isothermal for $2 \mathrm{~min}$ ) with an increase of $10^{\circ} \mathrm{C} / \mathrm{min}$, to $200^{\circ} \mathrm{C}$ then $5^{\circ} \mathrm{C} / \mathrm{min}$, to $280^{\circ} \mathrm{C}$, ending with a 9 min ISO thermal at $280^{\circ} \mathrm{C}$. Mass spectrum was taken at $70 \mathrm{eV}$ with a scan interval of 0.5 seconds and fragments from 45 to $450 \mathrm{Da}$. The Total GC running time was 36 minutes and the relative percentage of each component was calculated by comparing its average peak area to the total area in the NIST library [34].

\subsection{Biogenic fabrication of Ag NPs using $C$. subradiata extract}

$15 \mathrm{~mL}$ of aqueous lichen extract was added to $285 \mathrm{~mL}$ of $1 \mathrm{mM}$ Silver nitrate $\left(\mathrm{Ag} \mathrm{NO}_{3}\right)$ solution. The extract and salt combination was mixed well and allowed to react. The resultant solution was centrifuged at $10,000 \mathrm{~g}$ for 10 minutes. The supernatant was discarded and the pellet was dispersed in double distilled water and washed thrice to remove the unreacted $\mathrm{Ag} \mathrm{NO}_{3}$ and extract constituents [35]. The pellet was air dried and stored at $4^{\circ} \mathrm{C}$ for further experiments.

\subsubsection{Characterization of Silver nanoparticles}

The pellet, either directly or as redisposed in distilled water was used for the characterization procedures. The fabrication of the nanoparticles was confirmed using Ultra-Violet Visible (UV-Vis) spectroscopy (Shimadzu with a range of 200-800nm). Functional groups were identified using Fourier Transform Infrared (FTIR) spectrophotometer (Perkin Elmer, range 4000 to $500 \mathrm{~cm}^{-1}$ ). Powder X-ray Diffractrometer 
(XRD) (X' Pert Pro - PANalytic) was used for particle nature analysis. Morphology and average size of the particles were visualized and calculated from the Transmission electron microscope images (Joel/Jem 2100 HR-TEM operating at a voltage of $200 \mathrm{kv}$ ).

\subsection{Determination of Total Phenol Content (TPC) and Total flavonoid content (TFC)}

The total phenol content and flavonoid content of C.subradiata aqueous extract and AgNPs green synthesized using the same extract were evaluated by different spectroscopic methods. Different concentrations of the lichen extract $(20,40,60,80$ and $100 \mu \mathrm{g} / \mathrm{mL})$ and $\operatorname{AgNPs}(2,4,6,8$ and $10 \mu \mathrm{g} / \mathrm{mL})$ were used to perform the analysis. The TPC in the samples were determined using Folin-ciocalteau method [36] and TFC was determined using Aluminium chloride method [37]. The samples were measured for absorbance using a Shimadzu spectrophotometer $(200-800 \mathrm{~nm})$ in the wavelength $725 \mathrm{~nm}$ and $430 \mathrm{~nm}$ for the assays respectively.

\subsection{In-vitro antioxidant activity of $C$. subradiata extract and AgNPs}

The antioxidant activity of $C$. subradiata extract and AgNPs were determined using different in-vitro assays. Different concentrations of $C$. subradiata extract $(20,40,60,80$ and $100 \mu \mathrm{g} / \mathrm{mL})$ and AgNPs $(2,4$, 6,8 and $10 \mu \mathrm{g} / \mathrm{mL}$ ) were used. 2, 2-diphenyl-1-picrylhydrazyl (DPPH) free radical scavenging assay was performed by adding $2 \mathrm{ml}$ of DPPH solution in methanol to the aliquots of the samples. The mixture was allowed to react in dark for 30 minutes and the absorbance was measured at $517 \mathrm{~nm}$ [38]. ABTS $\left(2,2^{\prime}-\right.$ azino-bis(3-ethylbenzothiazoline-6-sulfonic acid)) free radical scavenging assay was done by adding diluted ABTS which was incubated in dark for 14 hours to the samples and incubated for 15 minutes. The absorbance of the samples was measured at $734 \mathrm{~nm}$ [39]. To perform the Hydrogen peroxide $\left(\mathrm{H}_{2} \mathrm{O}_{2}\right)$ free radical scavenging assay $40 \mathrm{mM} \mathrm{H}_{2} \mathrm{O}_{2}$ was added to the different aliquots of samples and incubated for 10 minutes. The absorbance of the samples was recorded at $230 \mathrm{~nm}$ [40]. Ascorbic acid was used as the positive control for all the assays and the free radical scavenging percentage of the samples were calculated as follows:

$\%$ inhibition $=[(A C-A S) / A C] \times 100$

Where AC is the absorbance of the control; AS is the absorbance of the sample

\subsection{In-vitro anticandida activity of $\boldsymbol{C}$. subradiata extract and AgNPs}

In-vitro anticandida activities of C. subradiata extract and synthesized AgNPs were evaluated by agar well-diffusion method. The samples were tested at different concentrations (15-100 $\mu \mathrm{g})$. Candida strains were obtained from Microbial Type Culture Collection and Gene Bank (MTCC), Chandigarh, India ( $C$. albicans -MTCC 183, C. tropicalis -MTCC 184, C.glabrata MTCC 3019, C.parapsilosis MTCC - 7043 and C. krusei-MTCC 9215). The assay was performed using Potato Dextrose Agar (PDA) as the culture 
medium and $0.1 \mathrm{~mL}$ of each inoculum was swabbed on individual petriplates and allowed to dry in order to assure the absorbance of the inoculum by PDA. Wells were cut using a cork borer and different concentrations of the samples were added to each well. Distilled water served as the negative control and standard antifungal agent Amphotericin B was used as the positive control. The plates were incubated at $37^{\circ} \mathrm{C}$ for 24 hours after which the zones of inhibition was observed and measured in millimetres [41].

\subsection{In- silico molecular docking of $C$. subradiata compounds}

Structure of chemical compounds identified using GC-MS analysis were obtained from the Pubchem database and the three-dimensional protein structure of EGFR protein involved in lung cancer pathogenesis was downloaded from RCSCB protein data bank (PDB) [42]. The Graphical User Interface program "AutoDock Tools" was used to prepare, run, and analyze the docking simulations. Koll man united atom charges, solvation parameters and polar hydrogen's were added into the receptor PDB file for the preparation of protein in docking simulation. Auto Dock requires pre-calculated grid maps, one for each atom type present in the flexible molecules being docked and its stores the potential energy arising from the interaction with rigid macromolecules. This grid must surround the region of interest in the rigid macromolecule. The grid box size was set at 126,126 and $126 A^{\circ}(x, y$, and $z)$ to include all the amino acid residues that present in rigid macromolecules. AutoGrid 4.2 Program, supplied with AutoDock 4.2 was used to produce grid maps. The spacing between grid points was 0.375 angstroms. The Lamarckian Genetic Algorithm (LGA) was chosen search for the best conformers. During the docking process, a maximum of 10 conformers was considered. The population size was set to 150 and the individuals were initialized randomly. Maximum number of energy evaluation was set to $25,00,000$, maximum number of generations 27,000 , maximum number of top individual that automatically survived set to 1 , mutation rate of 0.02 , crossover rate of 0.8 , Step sizes were $0.2 \mathrm{~A}$ for translations, $5.0^{\circ}$ for quaternions and $5.0^{\circ}$ for torsions. Cluster tolerance $0.5 \mathrm{~A}$, external grid energy $1,000.0$, max-initial energy 0.0 , max number of retries 10,000 and 10 LGA runs was performed. The best ligand-receptor structure from the docked structures was chosen based on the lowest energy and minimal solvent accessibility of the ligand. Docking results of each calculation were clustered on the basis of root mean square deviation (RMSD) between the Cartesian coordinates of ligands and were ranked according to binding energy [43].

\subsection{In- vitro cytotoxic activity of $C$. subradiata extract and AgNPs}

The human lung cancer cell line (A 549) was obtained from National Centre for Cell Science (NCCS), Pune and grown in Eagles Minimum Essential Medium containing 10\% fetal bovine serum (FBS). The cells were maintained at $37^{\circ} \mathrm{C}, 5 \% \mathrm{CO}_{2}, 95 \%$ air and $100 \%$ relative humidity. Maintenance of the cultures was done by weekly passaging and the culture medium was changed twice a week. $100 \mu \mathrm{L}$ per well of cell suspension were seeded into 96-well plates. After $24 \mathrm{~h}$ the cells were treated with serial concentrations of AgNPs. Following sample addition, the plates were incubated for an additional $48 \mathrm{~h}$ at $37^{\circ} \mathrm{C}, 5 \% \mathrm{CO}_{2}, 95 \%$ 
air and $100 \%$ relative humidity [44]. The medium without samples served as control and the experiments were performed in triplicate.

\section{Statistical analysis}

All the assays were performed in triplicates and expressed as mean \pm standard error. Origin 8 pro and Excel 2010 softwares were used for plotting the graphs.

\subsection{Results And Discussion \\ 3.1. Identification of lichen sample}

Kodaikanal hills of the Western Ghats region was a rich repository of several diverse lichen species. Crustose, foliose, fruiticose and squamulose lichens were documented during the survey and most of them belonged to the families Pyrenulaceae, Bacidiaceae, Physciaceae, Parmeliaceae, Cladonniaceae, Arthoniaceae, Graphidaceae, Trochotheliaceae and Ramalinaceae. Western Ghats region of Tamil Nadu has a wide assortment of lichens with more than 657 taxa among which some lichens still remain unexplored and the lichen Parmelia pseudobitteriana was identified for the first time from kodaikanal hills [45]. The lichen sample selected for the study was identified as C. subradiata (Fig. 1). The lichen was characterized by squamules of $2 \times 1 \mathrm{~mm}$ with whitish graypodetida sparingly branched. The tips were blunt in young poetida and mature tips formed cups. The surface was thinly corticated and the pycnidia were found in young basal squamules.

\subsection{Phytochemical screening of $C$. subradiata}

Methanol, ethanol, acetone, chloroform, aqueous, petroleum ether and hexane extracts of C.subradiatia were screened for the presence of phytochemicals. Table 1 shows the presence and absence of phytocompounds such as alkaloids, flavonoids, phenols, saponins, tannins, glycosides and sterols. Extraction of the phytocompounds was found to be high in mid-polar solvents such as acetone, chloroform and water. Chloroform extract exhibited strong results for flavonoids and phenols when compared to other extracts. The extraction quality was poor in petroleum ether and hexane suggesting the minimal quantity of non-polar groups in the phytocompounds. Alkaloids, phenols, flavonoids, saponins, glycosides and tannins are the frequently reported phytochemicals in lichen species [46]. Bodicherla et al., [47] has reported the presence of phytochemicals similar to our results in selected macrolichens in methanol, 2-propanol and water extracts. The phytochemicals in biological samples are considered as the major agents that are responsible for the rapid reduction of metal ions to metal nanoparticles in an eco-friendly manner [48]. 
Table 1

Phytochemical screening of different extracts of

C.subradiata

\begin{tabular}{|llllllll|}
\hline Phytochemicals & & & & & & & \\
\hline & M & E & Ac & C & Aq & P & H \\
\hline Alkaloids & - & - & + & + & - & - & - \\
\hline Flavonoids & + & + & + & + & + & - & - \\
\hline Saponins & - & - & + & + & + & - & - \\
\hline Tannins & - & + & - & + & - & + & - \\
Phenols & + & - & + & + & + & + & + \\
Glycosides & - & + & - & + & + & - & - \\
\hline Sterols & - & - & - & - & - & - & - \\
\hline
\end{tabular}

M: Methanol; E: Ethanol, Ac: Acetone, C: Chloroform, Aq: Aqueous; P: Petroleum ether; H: Hexane

+: presence of phytochemicals; - : absence of phytochemicals

\subsection{Identification of $C$. subradiata compounds using GC-MS analysis}

The results of the GC-MS analysis confirmed the presence of phytocompounds in the chloroform extract of C.subradiata. 34 phytoconstitents were identified from the chromatogram (Fig. 2) by comparing the NIST library compounds list. 2-methyltetracosane $\left(\mathrm{C}_{25} \mathrm{H}_{52}\right)$, Fumarprotocetraric Acid $\left(\mathrm{C}_{22} \mathrm{H}_{16} \mathrm{O}_{12}\right)$, 6Methoxy-2-hexanol $\left(\mathrm{C}_{7} \mathrm{H}_{16} \mathrm{O}\right)$,Protolichesterinic Acid $\left(\mathrm{C}_{19} \mathrm{H}_{32} \mathrm{O}_{4}\right)$,Perlatolinic Acid $\left(\mathrm{C}_{25} \mathrm{H}_{32} \mathrm{O}_{7}\right)$, 1 Heptadecanamine $\left(\mathrm{C}_{17} \mathrm{H}_{37}\right)$, 1-Tridecene $\left(\mathrm{C}_{13} \mathrm{H}_{26}\right)$, Atranorin $\left(\mathrm{C}_{19} \mathrm{H}_{18} \mathrm{O}_{8}\right)$, Usnic Acid $\left(\mathrm{C}_{18} \mathrm{H}_{16} \mathrm{O}_{7}\right)$, Phytol $\left(\mathrm{C}_{20} \mathrm{H}_{40} \mathrm{O}\right)$, Ethyl-2-Hydroxy-4-Methoxy-6-Pentylbenzoate $\left(\mathrm{C}_{11} \mathrm{H}_{14} \mathrm{O}_{4}\right)$ and Pulvinic Acid $\left(\mathrm{C}_{18} \mathrm{H}_{12} \mathrm{O}_{5}\right)$ were the major compounds identified from the chromatogram. The reports on GC-MS analysis of Parmelia perlata showed the presence of phytocompounds such as Atranorin, Usnic acid and benzoic acid which was parallel to our results [34]. Similarly the compound, Phytol was reported in the GC-MS analysis of Thamnolia subuliformis lichens from the western Himalayas [49].

\subsection{Biogenic synthesis and characterization of AgNPs synthesized from $C$. subradiata}

AgNPs were rapidly synthesized using C.subradiata chloroform extract which was confirmed from the visible colour change in the colloidal solution. The colour change from pale yellow to brown intensified with the increase in time (Fig. 3a). The Uv-Visible spectra of the synthesized AgNPs from the lichen extract showed surface plasmon bands between 420 and $450 \mathrm{~nm}$ at a time lapse of 5 to 180 minutes. 
The intensity of the bands stabilized after 60 minutes and was devoid of red and blue shifts (Fig. 3b). This indicates the stability of the bio-synthesized AgNPs using C.subradiata chloroform extract. Reports of Abdel-Raouf et al., [50] showed that bands were obtained between 400-500 nm for AgNPs synthesized from brown algae extracts and similarly Gudikandulaet al., [51] reported bands between 419-421 nm for AgNPs from white rot fungi. These reports run parallel with our report as lichens are symbionts of algae and fungi. The FT-IR spectrum (Fig. 4) revealed the functional groups of the AgNPs synthesized using $C$. subradiata chloroform extract. Peak at $3438 \mathrm{~cm}^{-1}$ corresponds to $\mathrm{O}-\mathrm{H}$ stretch of alcohol, the peak at $1416 \mathrm{~cm}^{-1}$ is attributed to $\mathrm{C}=\mathrm{C}$ stretch of alkenes and peak at $1107 \mathrm{~cm}^{-1}$ is designated to $\mathrm{C}-\mathrm{N}$ for amide or nitro groups. Peaks obtained belonged to the functional groups such as alcohol, nitro compounds, amides and alkenes respectively. The presence of amide and nitro groups showed that other than secondary metabolites, proteins play a major role in the reduction and capping of AgNPs[52]. The X-ray diffraction pattern (Fig. 5) of AgNPs synthesized from C.subradiata chloroform extractcorresponded to (111), (200), (220) and (311) crystallographic planes of face centred cubic (FCC) Silver. Debye-Scherrer formula $(D=0.94 \lambda / \beta \cos \theta)$ was used to calculate the average size of the AgNPs. The average size of the AgNPs synthesized from C.subradiata chloroform extract was $23 \mathrm{~nm}$. The results were in accordance with the Braggs reflection of silver nanocrystals [53]. The morphological characteristics of the AgNPs were investigated using a TEM instrument. The micrographs (Fig. 6a) revealed that the AgNPs synthesized from lichen extracts were predominantly spherical in shape and their size ranged between 20-50 nm. The crystalline nature of the nanoparticles was evident from the SAED pattern (Fig. 6b) and coincided with the XRD results. Biogenic fabrication of Ag NPs using aqueous-ethanolic extract of Usnea longissima yielded NPs within the size range of 9-11 nm with enhanced antibacterial activity, phytocompounds of the lichen extract were suggested to be the vital reducing and capping agents [54].

\subsection{Total phenol and flavonoids content in C. subradiata chloroform extract and AgNPs}

The results of the TPC and TFC exhibited by $C$. subradiata chloroform extract and AgNPs are given Table 2. It is shown that $C$. subradiata chloroform extract showed high TPC and TFC. Considerable amounts of phenols and flavonoids were detected in the Ag NPs synthesized from the lichen extract. The highest TPC (163.41 $\pm 0.3 \mathrm{mg} \mathrm{GAE} / \mathrm{g})$ and TFC $(88.72 \pm 0.01 \mathrm{mg} \mathrm{GAE} / \mathrm{g})$ were expressed in $C$. subradiata chloroform extract at a concentration of $100 \mu \mathrm{g} / \mathrm{mL}$. Green synthesized Ag NPs using Tridax procumbens exhibited $68.93 \pm 0.36 \mu \mathrm{g} / \mathrm{mg}$ GAE and $64.98 \pm 0.46 \mu \mathrm{g} / \mathrm{mg}$ QE as TPC and TFC at $1 \mathrm{mg} / \mathrm{mL}$ concentration [55]. It is evident from our results that the content of flavonoids and phenols increased with the increase in the concentration of the sample, therefore it can be suggested that the TPC and TFC contents of the AgNPs synthesized from chloroform extract of $C$. subradiata might increase with the increase in the concentration. 
Table 2

Total phenol and flavonoid content $C$. subradiata chloroform extract and Ag NPs

\begin{tabular}{rlllllllll} 
Sample & \multicolumn{2}{l}{ Chloroform extract $(\mu \mathrm{g} / \mathrm{ml})$} & \multicolumn{7}{l}{ Ag NPs $(\mu \mathrm{g} / \mathrm{ml})$} \\
\cline { 2 - 5 } & $20 \mu \mathrm{g} \quad 40 \mu \mathrm{g} \quad 60 \mu \mathrm{g}$ & $80 \mu \mathrm{g}$ & $100 \mu \mathrm{g}$ & $2 \mu \mathrm{g}$ & $4 \mu \mathrm{g}$ & $6 \mu \mathrm{g}$ & $8 \mu \mathrm{g}$ & $10 \mu \mathrm{g}$
\end{tabular}

\begin{tabular}{|c|c|c|c|c|c|c|c|c|c|c|}
\hline TPC & $\begin{array}{l}16.11 \\
\pm 1.3\end{array}$ & $\begin{array}{l}53.51 \\
\pm 0.3\end{array}$ & $\begin{array}{l}103.69 \\
\pm 0.7\end{array}$ & $\begin{array}{l}118.6 \\
\pm 0.33\end{array}$ & $\begin{array}{l}163.41 \\
\pm 0.12\end{array}$ & $\begin{array}{l}2.16 \\
\pm \\
0.14\end{array}$ & $\begin{array}{l}7.85 \\
\pm \\
1.12\end{array}$ & $\begin{array}{l}9.31 \\
\pm 0.7\end{array}$ & $\begin{array}{l}12.91 \\
\pm 0.3\end{array}$ & $\begin{array}{l}16.82 \\
\pm 0.02\end{array}$ \\
\hline TFC & $\begin{array}{l}7.76 \\
\pm 0.4\end{array}$ & $\begin{array}{l}34 \pm \\
0.02\end{array}$ & $\begin{array}{l}53.7 \pm \\
2.3\end{array}$ & $\begin{array}{l}64.18 \\
\pm 0.6\end{array}$ & $\begin{array}{l}88.72 \\
\pm 0.01\end{array}$ & $\begin{array}{l}0.96 \\
\pm 0.1\end{array}$ & $\begin{array}{l}5.48 \\
\pm \\
0.01\end{array}$ & $\begin{array}{l}6.44 \\
\pm \\
0.12\end{array}$ & $\begin{array}{l}8.3 \pm \\
0.1\end{array}$ & $\begin{array}{l}12.41 \\
\pm 0.2\end{array}$ \\
\hline
\end{tabular}

Results are expressed as mean values $(n=3) \pm$ standard error

\subsection{In-vitro antioxidant activity of $C$. subradiata extract and AgNPs}

Figure 7 shows the comparative antioxidant activity of $C$. subradiata extract and AgNPs. AgNPs synthesized from $\mathrm{C}$. subradiata extract exhibited potent free radical scavenging activity. AgNPs showed an inhibitory percentage of $97.51 \pm 0.2 \%, 89.71 \pm 0.00 \%$ and $91.46 \pm 1.2 \%$ for DPPH, ABTS and $\mathrm{H}_{2} \mathrm{O}_{2}$ radicals respectively. The $\mathrm{IC}_{50}$ values of AgNPs for the assays were $7.51 \pm 0.4 \mu \mathrm{g}, 14.26 \pm 0.02 \mu \mathrm{g}$ and $9.61 \pm 2.1 \mu \mathrm{g}$ whereas $\mathrm{IC}_{50}$ values of the lichen extract was $46.24 \pm 0.3 \mu \mathrm{g}, 61.79 \pm 0.001 \mu \mathrm{g}$ and $53.22 \pm$ $0.21 \mu \mathrm{g}$. Free radicals that are produced during various metabolic pathways in the human system can lead to development of several fatal diseases such as cancer. Antioxidants play an inevitable role in neutralizing or nullifying the effect of free radicals and management of fatal diseases. Phenols and flavonoids in plant extracts are suggested as to be excellent free radical scavenging agents. The potent antioxidant activity exhibited by the AgNPs was due to the phytocompounds that act as reducing and capping agents [35].

\subsection{In-vitro anticandida activity of $C$. subradiata extract and AgNPs}

Anticandida activity of the Ag NPs synthesized from C. subradiata extract was tested against five candida strains and the zone of inhibition (ZOI) measured for the strains ranged from $7.3 \pm 0.72 \mathrm{~mm}$ to $17 \pm 1.12 \mathrm{~mm}$. The ZOI observed for $C$. subradiata chloroform extract ranged from $0.3 \pm 1.3 \mathrm{~mm}$ to $5.7 \pm$ $0.9 \mathrm{~mm}$. The order of susceptibility of the strains was as follows for AgNPs: $C$. albicans $\geq C$. tropicalis $\geq$ C. krusei $\geq$ C. glabrata $\geq$ C. parapsilosis, whereas the susceptibility order of the lichen extract was observed to be: $C$. albicans $\geq C$. krusei $\geq C$. tropicalis $\geq C$. parapsilosis $\geq C$. glabrata (Fig. 8). C.albicans was highly susceptible to the treatment of Ag NPs and $C$. subradiata chloroform extract. It was evident from the well diffusion assay that the inhibition pattern was concentration dependent. The ZOls ranged 
from $22.3 \pm 1.4 \mathrm{~mm}$ to $25.7 \pm 0.7 \mathrm{~mm}$. The activity of 38 lichen extracts were found to have poor inhibitory effects on planktonic $C$. albicans yeast and an MIC of $500 \mu \mathrm{g}$ and above were reported [56]. This suggests that phytocompounds present in lichen extracts were least effective against candida species and was in correspondence with our results. However Ag NPs synthesized from seed extract of Syzygium cumini was reported to have an MIC value of $0.125 \mathrm{mg}-0.250 \mathrm{mg} / \mathrm{mL}$ against Candida sp.[57]. Similarly the ZOI of Curcumin- Ag NPs was observed as $22.2 \pm 0.8 \mathrm{~mm}, 20.1 \pm 0.8 \mathrm{~mm}$, and $16.4 \pm 0.7 \mathrm{~mm}$ against C. glabrata, $C$. albicans and $C$. tropicalis respectively [58]. Results of the anticandida assay suggest that AgNPs synthesized form $C$. subradiata can be considered as promising anticandida agents.

\subsection{In- silico molecular docking of $C$. subradiata compounds against lung cancer protein}

In-silico molecular docking was performed using the structure of seven compounds identified by GC-MS analysis of $C$. subradiata chloroform extract using Autodock 4.2. From the analysis, six out of seven compounds showed hydrogen bond interactions. Docked pose of the different compounds with EGFR protein (PDB Id:2GS2). Hydrogen bond interactions, the information about the Binding energies, Number of hydrogen bonds formed and the distance between them is given in Table 3. From the analysis, it is observed that Pulvinic acid and Usnic acid has least binding energy and showed remarkable hydrogen bond interactions with EGFR protein (Fig. 9). Usnic acid suppresses angiogenesis of breast cancer by successfully inhibiting vascular endothelial growth factor receptor (VEGFR) 2 mediated Extracellular signal-regulated protein kinases 1 and 2(ERK1/2) and AKT/P70S6K signaling pathways in endothelial cells [59]. Phytocompounds from the fruticose lichen Rocella montagnei showed impressive docking scores against CDK-10 (Cyclin Dependent Kinase 10) that plays a pivotal role in the pathogenesis of cancer and is attributed for the incessant proliferation of cancer cells [60]. Lichen metabolites are also known to inhibit the activity of cyclooxygenase-2 enzyme which is involved in the inflammation of tissues [61]. Molecular docking results of this study provide a new arena for exploring the anti-cancer potential of lichen metabolites against lung cancer proteins. 
Table 3

In-silico molecular docking of compounds from C. subradiata chloroform extract and their interactions

\begin{tabular}{|c|c|c|c|}
\hline Compound Name & $\begin{array}{l}\text { Binding } \\
\text { energy }\end{array}$ & $\begin{array}{l}\text { Hydrogen bond } \\
\text { interaction }\end{array}$ & Distance \\
\hline \multirow[t]{3}{*}{ Atranorin } & \multirow[t]{3}{*}{-4.73} & ARG812(H...O) & 3.3 \\
\hline & & LYS836(HZ...O) & 3.1 \\
\hline & & PHE832(O...H) & 3.4 \\
\hline \multirow[t]{4}{*}{ Usnic acid } & \multirow[t]{4}{*}{-6.02} & TYR740(H....0) & 2.7 \\
\hline & & ARG807(H....O) & 2.6 \\
\hline & & ARG808(H....0) & 2.7 \\
\hline & & LEU837(O....H) & 2.2 \\
\hline Perlatolinic acid & -5.56 & LYS704(H...0) & 2.6 \\
\hline \multirow{3}{*}{$\begin{array}{l}\text { Ethyl-2-hydroxy-4-methoxy-6- } \\
\text { pentylbenzoate }\end{array}$} & \multirow[t]{3}{*}{-4.64} & LEU679(HN...O) & 4.0 \\
\hline & & ARG752(HH...O) & 2.9 \\
\hline & & $\operatorname{ALA743(O...H)~}$ & 2.1 \\
\hline \multirow[t]{2}{*}{ Protolichesterinic acid } & \multirow[t]{2}{*}{-4.74} & LYS692(HZ...O) & 2.8 \\
\hline & & LYS704(HZ ...0) & 2.8 \\
\hline \multirow[t]{2}{*}{ Pulvinic acid } & \multirow[t]{2}{*}{-7.39} & LYS692(HZ...0) & 2.6 \\
\hline & & LYS704(HZ...O) & 2.8 \\
\hline
\end{tabular}

\subsection{In- vitro cytotoxic activity of $C$. subradiata extract and AgNPs}

In-vitro cytotoxic activity of $\mathrm{C}$. subradiata chloroform extract and AgNPs synthesized from the same extract were carried out owing to the encouraging results obtained from in-silico molecular docking study using the structures of $C$. subradiata extract compounds identified by GC-MS analysis. The effects of $C$. subradiata extract and AgNPson cell viability were analysed and quantified by using MTT assay after 24hour treatment with a concentrations of the samples ranging from 3 to $300 \mu \mathrm{g} / \mathrm{mL}$ (Fig. 10). Through this assay, cell viability was determined based on the measurement of mitochondrial function, as MTT is transformed into formazan crystals in living cells in which mitochondrial dehydrogenases are functional. As shown in Fig. 10, cell viability decreased in a concentration-dependent manner in human lung cancer cells (A549). The lichen extract possessed cytotoxic activity towards human lung cancer cell line (A549). An $\mathrm{IC}_{50}$ value of $28.75 \mu \mathrm{g} / \mathrm{mL}$ and $254.08 \mu \mathrm{g} / \mathrm{mL}$ was obtained for AgNPs and the lichen extract respectively. AgNPs synthesized from Syzygium aromaticum extract exhibited potential cytotoxic activity against $A 549$ lung cancer cells and the $\mathrm{IC}_{50}$ value was reported as $50 \mu \mathrm{g} / \mathrm{mL}[62]$. In another study, the 
$\mathrm{IC}_{50}$ value of AgNPs synthesized from Momordica charantia against A549 cells was $51.93 \mu \mathrm{g} / \mathrm{mL}$ [63].

The $\mathrm{IC}_{50}$ value obtained in this study was comparatively less and exhibited potential cytotoxic effects. The mechanism of action of AgNPs dependent cancer cell death is owed to the generation of intracellular reactive oxygen species. Over production of free radicals leads to oxidative stress, thus damaging the DNA of the cancer cells and forcing them to enter apoptosis. Morphology, size, charges of the AgNPs are crucial in determining the cytotoxic effect $[64,65]$. Bio-active compound based metal nanoparticles have also showed excellent cytotoxic activity against A549 cells, in a study Palladium nanoparticles synthesized using ascorbic acid by microwave irradiation method showed an $\mathrm{IC}_{50}$ of $7.2 \pm 1.7 \mathrm{ug} / \mathrm{mL}[66]$. However the results of our study suggested that simple and facile synthesis are cost-effective in yielding AgNPs with similar cytotoxic effects.

\subsection{Conclusion}

The present study elucidated a greener, safer, eco-friendly, feasible and rapid alternative approach to synthesize Silver nanoparticles with enhanced biological applications. C. subradiata lichen extract was a successful green resource for the synthesis of AgNPs and are identified to have rich secondary metabolite profile. Lichen extract and synthesized AgNPs showed substantial amounts of phenol and flavonoid content with effective free radical scavenging activity and anticandida activity. The in-silico study explicated the effective binding and interaction of C.subradiata compounds with EGFR lung cancer protein. In-vitro cytotoxicity assay revealed the dose dependent effect of AgNPs and lichen extract on A549 cells with a low $\mathrm{IC}_{50}$ value. The results present vital evidence that cost-effective synthesis of AgNPs from $C$. subradiata lichen extract and their anti-cancer properties have potential applications against lung cancer in the field of nanomedicine.

\section{Declarations}

\section{Acknowledgement}

The authors would like to thank Lichenologist Dr.Sanjeeva Nayaka, Senior Principal Scientist, National Botanical Research Institute, Lucknow for his kind gesture in lichen identification. Author (PB) thankfully acknowledge the UGC-Innovative [No. F. 14-13/2013 (Inno/ASIST)], DST-FIST [SR/FST/LSI- 667/2016(C)], DST PURSE [SR/PURSE Phase 2/38 (G)], and MHRD-RUSA 2.0 [F.24/51/2014-U, Policy (TNMulti-Gen), Dept. of Edn. Govt. of India] for the financial supports and infrastructure facilities. The author M. H. A is very thankful for Taif University researcher supporting project Number TURSP/91, Taif University, Taif, Saudi Arabia.

\section{Conflict of Interest}

The authors declare that there is no conflict of interest. 


\section{References}

1. B.C. Bade, C.S. Dela, Clin. Chest. Med. 41, 1-24 (2020). doi:10.1016/j.ccm.2019.10.001

2. M. Ng, M.K. Freeman, T.D. Fleming, M. Robinson, L. Dwyer-Lindgren, B. Thomson, A. Wollum, E. Sanman, S. Wulf, A.D. Lopez, C.J. Murray, E. Gakidou JAMA. 311, 183-192 (2014). doi:10.1001/jama.2013.284692

3. F. Bray, J. Ferlay, I. Soerjomataram, R.L. Siegel, L.A. Torre, A. Jemal, CA: Cancer J.Clin. 68, 394-424 (2018). doi:10.3322/caac.21492

4. L.A. Torre, R.L. Siegel, A. Jemal, Adv. Exp. Med. Biol. 893, 1-19 (2016)

5. R. Siegel, E. Ward, O. Brawley, A. Jemal, CA: Cancer J.Clin. 61, 212-236 (2011). doi:10.3322/caac. 20121

6. T.W. Wang, K. Asman, A.S. Gentzke, K.A. Cullen, E. Holder-Hayes, C. Reyes-Guzman, B.A. King, MMWR. 67, 1225-1232 (2018). doi:10.15585/mmwr.mm6744a2

7. D. Hardy, C.C. Liu, R. Xia, J.N. Cormier, W. Chan, A. White, K. Burau, X.L. Du, Cancer. 115, 2199-2211 (2009). doi:10.1002/cncr.24248

8. A. Jemal, M. Thun, X.Q. Yu, A.M. Hartman, V. Cokkinides, M.M. Center, H. Ross, E.M. Ward, BMC Public Health. 11, 512 (2011). doi:10.1186/1471-2458-11-512

9. E. Szabo, J.T. Mao, S. Lam, M.E. Reid, R.L. Keith, Chest. 143:e40S-e60S (2013) doi: 10.1378/chest.122348

10. M.A. Alqahtani, M.R. Al Othman, A.E. Mohammed, Sci. Rep. 10 (2020). doi:10.1038/s41598-02073683-z

11. T.T.H. Nguyen, M.H. Dinh, H.T. Chi, S.-L. Wang, Q. Nguyen, T.D. Tran, A.D. Nguyen, Res. Chem. Intermed. 45, 33-49 (2018). doi:10.1007/s11164-018-3628-1

12. Z.A. Ratan, M.F. Haidere, M. Nurunnabi, S.M. Shahriar, A. Ahammad, Y.Y. Shim, M. Reaney, J.Y. Cho, Cancers. 12, 855 (2020). doi:10.3390/cancers12040855

13. X. Li, H. Xu, Z.S. Chen, G. Chen, J. Nanomater 2011, 1-16 (2011). doi:10.1155/2011/270974

14. P. Singh, Y.-J. Kim, D. Zhang, D.-C.0 Yang, Trends Biotechnol 34, 588-599 (2016). doi:10.1016/j.tibtech.2016.02.006

15. K.S. Siddiqi, M. Rashid, A. Rahman, T.A. Husen, S. Rehman, Biomat. Res.22,23 (2018). doi:10.1186/s40824-018-0135-9

16. K. Saravanakumar, R. Chelliah, D. MubarakAli, D.H. Oh, K. Kathiresan, M.H. Wang Sci. Rep. 9, 5787 (2019). doi:10.1038/s41598-019-42112-1

17. N.M. Al Sufyani, N.A. Hussien, Y.M. Hawsawi, J. Nanomater. 2019: 1-9 (2019). doi:10.1155/2019/7361695

18. K. Satyavani, S. Gurudeeban, T. Ramanathan, T. Balasubramanian, Avicenna. J. Med. Biotechnol. 4, 35-39 (2012) 
19. Y.G. Yuan, S. Zhang, J.-Y. Hwang, I.-K. Kong, Oxid. Med. Cell. Longev 2018, 1-21 (2018). doi:10.1155/2018/6121328

20. S.E. Fard, F. Tafvizi, M.B. Torbati, IET Nanobiotechnol 12, 994-1002 (2018). doi:10.1049/ietnbt.2018.5069

21. V.S. Madamsetty, A. Mukherjee, S. Mukherjee, Front. Pharm. 10 (2019). doi:10.3389/fphar.2019.01264

22. C.B.S. Tomasi, F. Lohézic-Le, J. Dévéhat, Boustie, Phytomedicine 10, 499-503 (2003). doi:10.1078/094471103322331458

23. F. Brisdelli, M. Perilli, D. Sellitri, M. Piovano, J.A. Garbarino, M. Nicoletti, A. Bozzi, G. Amicosante, G. Celenza, Phytother. Res. 27, 431-437 (2013). doi:10.1002/ptr.4739

24. B.M. Ramos, D. de, F.S. Gomes, T.H. Napoleão, P.M.G. Paiva, M.D.C. da Silva, L.C.B. Barroso Coelho, Chin. J. Biol. 2014, 1-7 (2014). doi:10.1155/2014/219392

25. M.T. Saenz, M.D. Garcia, J.G. Rowe, Fitoterapia 77, 156-159 (2006)

26. S. Ristić, B. Ranković, M. Kosanić, T. Stanojković, S. Stamenković, P. Vasiljević, I. Manojlović, N. Manojlović, J. Food. Sci. Tech. 53, 2804-2816 (2016). doi:10.1007/s13197-016-2255-3

27. V. Shukla, G.P. Joshi, M.S.M. Rawat, Phytochem. Rev. 9, 303-314 (2010)

28. M.E. Conti, G. Cecchetti, Environ. Pollut. 114, 471-492 (2001). doi:10.1016/s0269-7491(00)00224-4 29. K. Molnár, E. Farkas, Z. Naturforsch. C. 65, 157-173 (2010). doi:10.1515/znc-2010-3-401 30. Q.W. Zhang, L.G. Lin, W.C. Ye, Chin. Med. 13, 20 (2018). doi:10.1186/s13020-018-0177-x 31. J.B. Harborne, Phytochemical methods. London chapman and Hall Itd, 49-188(1984) 32. J. Brunton, Text Book of Pharmacognosy, Phytochemistry and Medicinal Plants Intercept Limited Springer London 592-593(1995)

33. H.M. Wagner, S. Bladt, E.M. Zgainski Plant drug analysis (Springer-Verlag, New York, 1984). : 320p 34. P. Pratibha, C. Mahesh, Int. J. Pharmacogn. Phytochem 8, 1975-1985 (2016)

35. Y.K. Mohanta, S.K. Panda, R. Jayabalan, N. Sharma, A.K. Bastia, T.K. Mohanta Front. Mol. Biosci. 4, 14 (2017). doi:10.3389/fmolb.2017.00014

36. I. Haq, N. Ullah, G. Bibi, S. Kanwal, M.S. Ahmad, B. Mirza, Iran. Journ. Pharm. Res. 11, 241-249 (2012)

37. C.C. Chang, M.H. Yang, H.M. Wen, J.C. Chern, J. Food Drug Anal. 10, 178-182 (2002)

38. B. Mahdi-Pour, S.L. Jothy, L.Y. Latha, Y. Chen, S. Sasidharan, Asian Pac.J. Trop. Biomed. 2, 960-965 (2012). doi:10.1016/S2221-1691(13)60007-6

39. F. Abu, M.C.N. Taib, M.A. Moklas, M.S. Akhir Altern. Med 2017, 1-9 (2017). doi:10.1155/2017/2907219

40. K. AsokKumar, M. UmaMaheswari, A.T. Sivashanmugam, V. SubhadraDevi, N. Subhashini, T.K. Ravi Pharm. Biol. 47, 474-482 (2009). doi:10.1080/13880200902817901 
41. E.J. Mallmann, F.A. Cunha, B.N. Castro, A.M. Maciel, E.A. Menezes, P.B. Fechine Rev. Inst. Med. Trop. 57, 165-167 (2015). doi:10.1590/S0036-46652015000200011

42. R. Padmini, U.V. Maheshwari, P. Saravanan, K. Lee, M. Razia, M. Alwahibi, B. Ravindran, M. Elsheikh, Y. Kim, H. Kim, H-J. Kim Saudi J. Biol. Sci. 27 (2020). 10.1016/j.sjbs.2020.09.041

43. R. Padmini, M. Razia, V. Roopavahini, S.S. Aruna, IJCRAR 3, 207-218 (2016)

44. P. Rajendran, U.V. Maheshwari, A. Muthukrishnan, R. Muthuswamy, K. Anand, B. Ravindran, P. Dhanaraj, B. Balamuralikrishnan, S.W. Chang, W.J. Chung, Mol. Cell. Biochem. 476, 57-68 (2021). doi:10.1007/s11010-020-03885-6

45. M. Mariraj, R. Kalidoss, K. Vinayaka, S. Nayaka, P. Ponnusamy, Curr. Bot 11, 138-141 (2020). doi:10.25081/cb.2020

46. S. Rashmi, H.G. Rajkumar, J.Pharmacogn. Phytochem. 3, 209-212 (2014) ISSN 2278-4136

47. A. Bodicherla, S. Mohabe, M.R. Araveeti, S. Nayaka, S. Akkulanna, CBAJ. 2 (2017). doi:10.21756/cab.v2i1.8391

48. S. Ahmed, M. Ahmad, B.L. Swami, S. Ikram, J. Adv. Res.7: 17-28 (2016). Doi: 0.1016/j.jare.2015.02.007

49. V. Pant, P.B. Rao, Pharm.Innov. 7, 82-88 (2018)

50. N. Abdel-Raouf, N.M. Al-Enazi, I.B.M. Ibraheem, R.M. Alharbi, M.M. Alkhulaifi Saudi J. Biol. Sci. 26, 1207-1215 (2018). doi:10.1016/j.sjbs.2018.01.007

51. K. Gudikandula, P. Vadapally, S.M.A. Charya, OpenNano. 2, 64-78 (2017). doi:10.1016/j.onano.2017.07.002

52. D. Ballottin, S. Fulaz, M.L. Souza, P. Corio, A.G. Rodrigues, A.O. Souza, P.M. Gaspari, A.F. Gomes, F. Gozzo, L. Tasic, NRL. 11, 313 (2016). doi:10.1186/s11671-016-1538-y

53. M. Gomathi, P.V. Rajkumar, A. Prakasam, K. Ravichandran Resource-Efficient Technologies 3, 280284 (2017). doi:10.1016/j.reffit.2016.12.005

54. G. Marslin, K. Siram, Q. Maqbool, R.K. Selvakesavan, D. Kruszka, P. Kachlicki, G. Franklin, Materials. 11, 940 (2018). doi:10.3390/ma11060940

55. R. Rani, D. Sharma, M. Chaturvedi, J.P. Yadav Chem Pap 74, 1817-1830 (2020). doi:10.1007/s11696019-01028-w

56. M. Millot, M. Girardot, L. Dutreix, L. Mambu, C. Imbert, Molecules 22, 651 (2017). doi:10.3390/molecules22040651

57. M. Jalal, M.A. Ansari, M.A. Alzohairy, S.G. Ali, H.M. Khan, A. Almatroudi, M.I. Siddiqui, Int.J. Nanomedicine 14, 4667-4679 (2019). doi:10.2147/IJN.S210449

58. S. Paul, K. Mohanram, I. Kannan, AYU 39, 182-186 (2018)

59. Y. Song, F. Dai, D. Zhai, Y. Dong, J. Zhang, B. Lu, J. Luo, M. Liu, Z. Yi, Angiogenesis 15, 421-432 (2012). doi:10.1007/s10456-012-9270-4

60. T. Mishra, S. Shukla, S. Meena, R. Singh, M. Pal, D.K. Upreti, D. Datta, Rev. Bras. Farmacogn. 27, 724728 (2017). doi:10.1016/j.bjp.2017.07.006 
61. M.F. Khan, S. Nabila, R. Rashid, M. Rahman, A. Chowdhury, M. Rashid, Bangladesh Pharm. J. 18, 9096 (2015). 10.3329/bpj.v18i2.24304

62. K. Venugopal, H.A. Rather, K. Rajagopal, M.P. Shanthi, K. Sheriff, M. Illiyas, M. Maaza, J. Photoch.Photobio. B. 167, 282-289 (2017). doi:10.1016/j.jphotobiol.2016.12.013

63. M. Jha, N.G. Shimpi, J. Gen, Eng. Biotechnol. 16, 115-124 (2018). doi:10.1016/j.jgeb.2017.12.001

64. W. Yang, C. Shen, Q. Ji, H. An, J. Wang, Q. Liu, Z. Zhang, Nanotechnology 20, 085102 (2009). doi:10.1088/0957-4484/20/8/085102

65. K.K. Awasthi, A. Awasthi, N. Kumar, P. Roy, K. Awasthi, P.J. John, J. Nanoparticle Res. 15, 1898 (2013). doi:10.1007/s11051-013-1898-5

66. A. Ameri, M. Shakibaie, H.R. Rahimi, M. Adeli-Sardou, M. Raeisi, A. Najafi, H. Forootanfar Biol Trace Elem Res 197, 132-140 (2020). doi:10.1007/s12011-019-01984-0

\section{Figures}

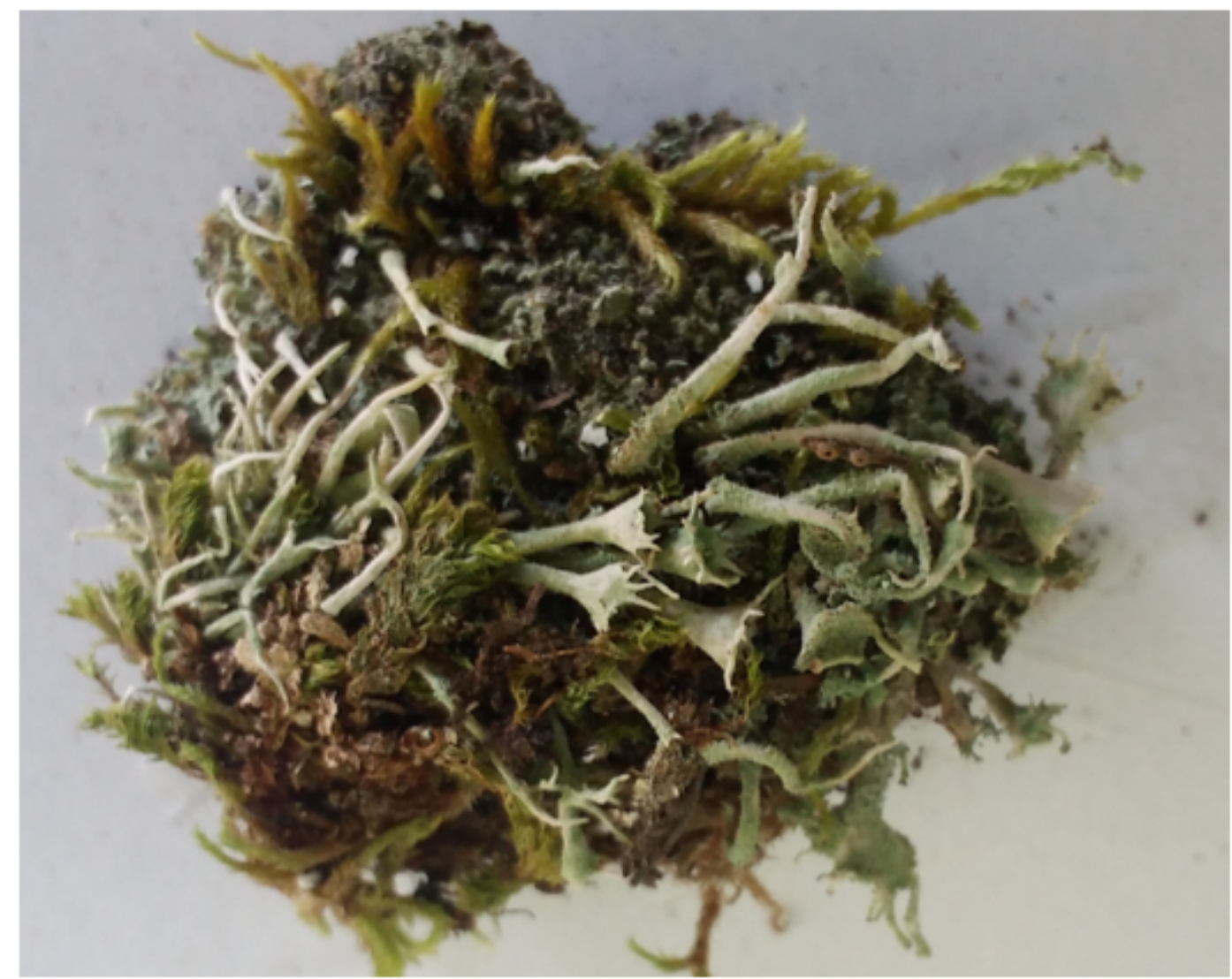

Figure 1

High altitude squamulose lichen- Cladonia subradiata 


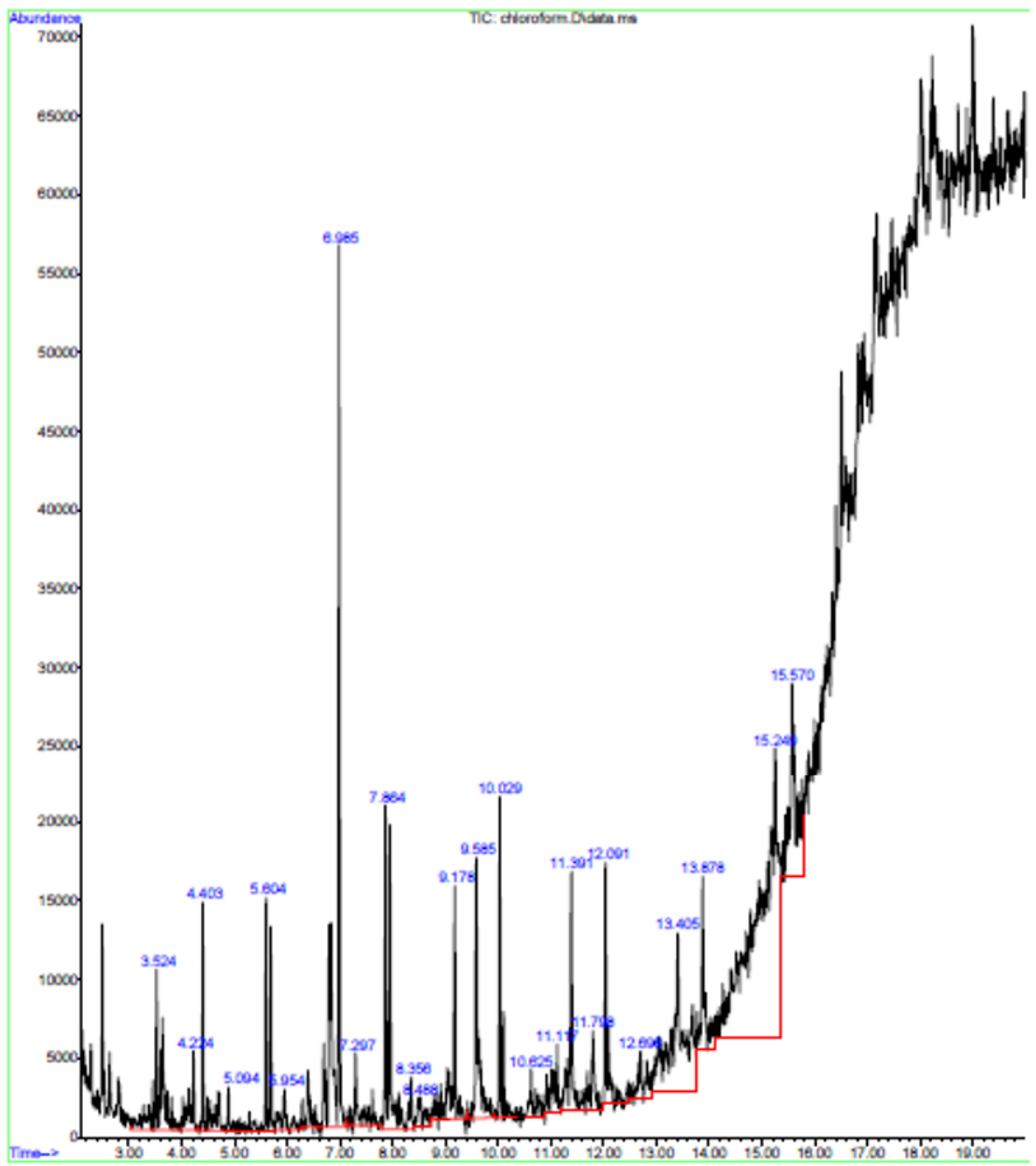

Figure 2

GC-MS chromatograph of C.subradiata chloroform extract 


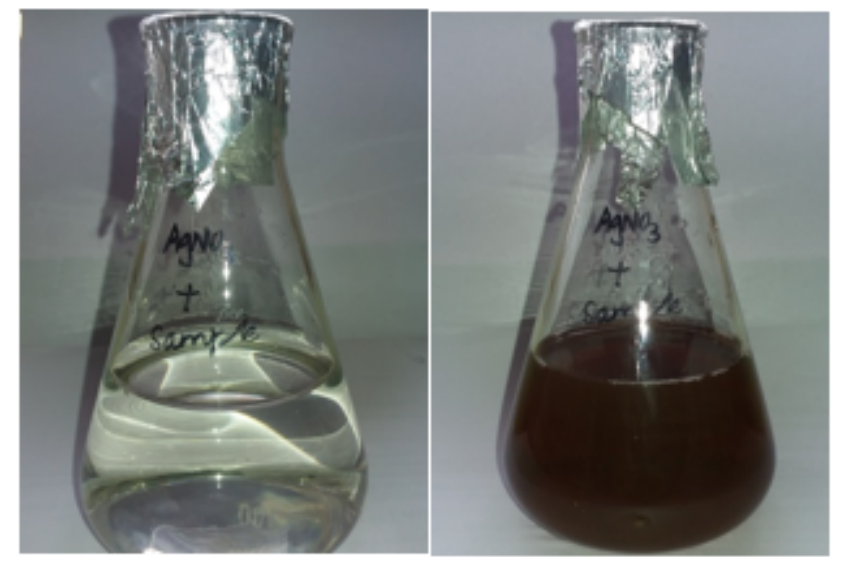

(a)

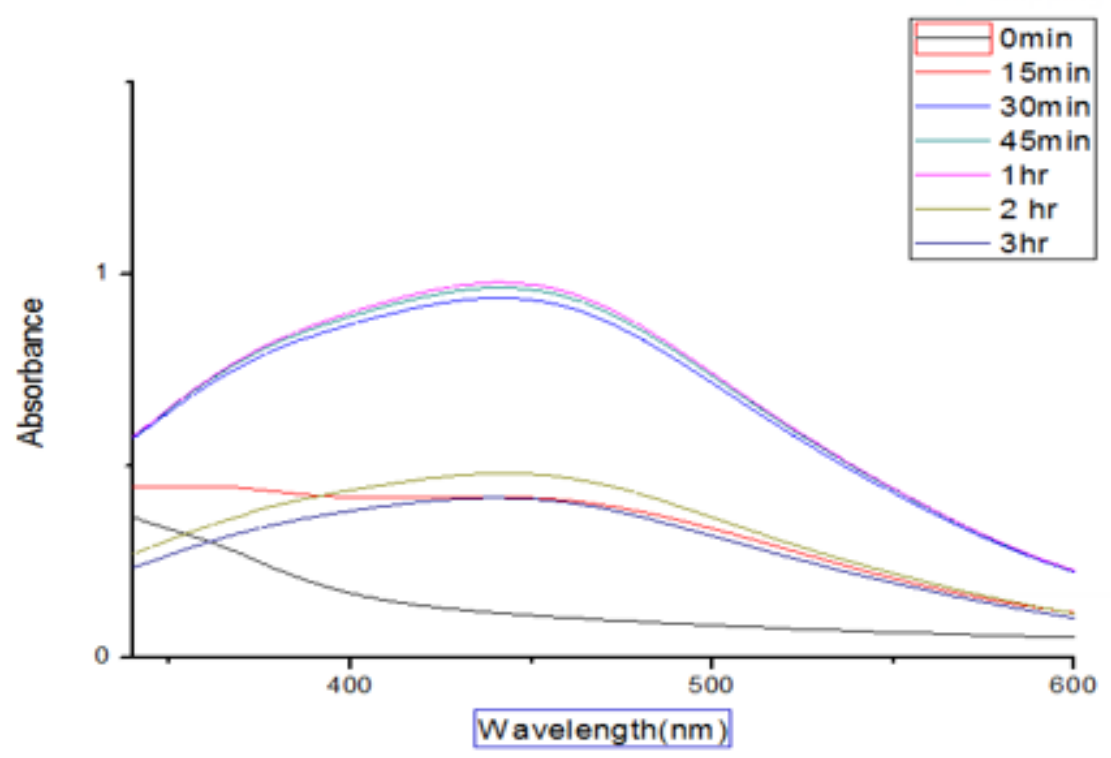

(b)

\section{Figure 3}

(a) Synthesis of Ag NPs from C. subradiata chloroform extract (b) UV-Vis spectrum of synthesized Ag NPs at regular time intervals 


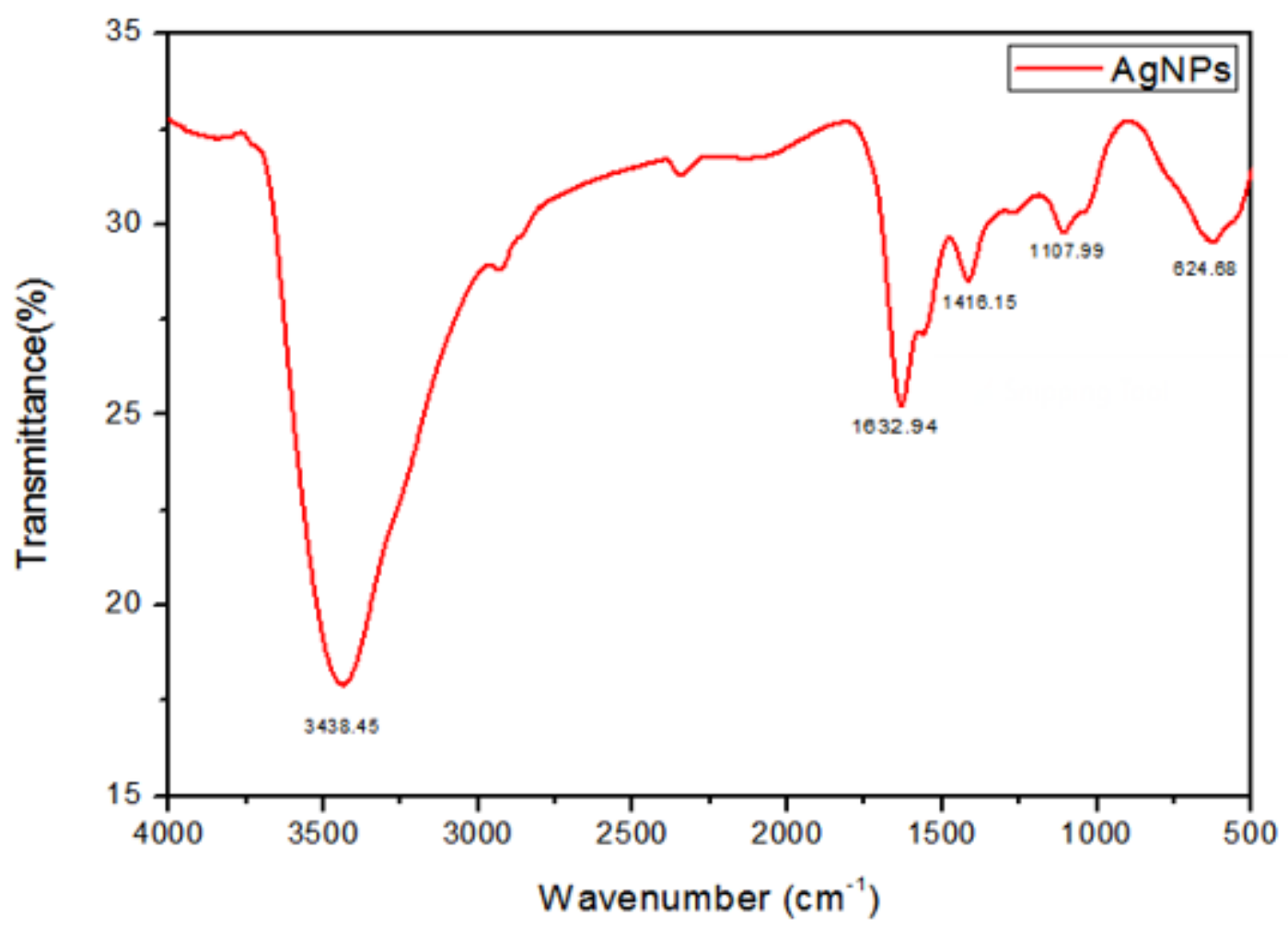

Figure 4

FTIR spectrum of Ag NPs synthesized from C. subradiata chloroform extract 


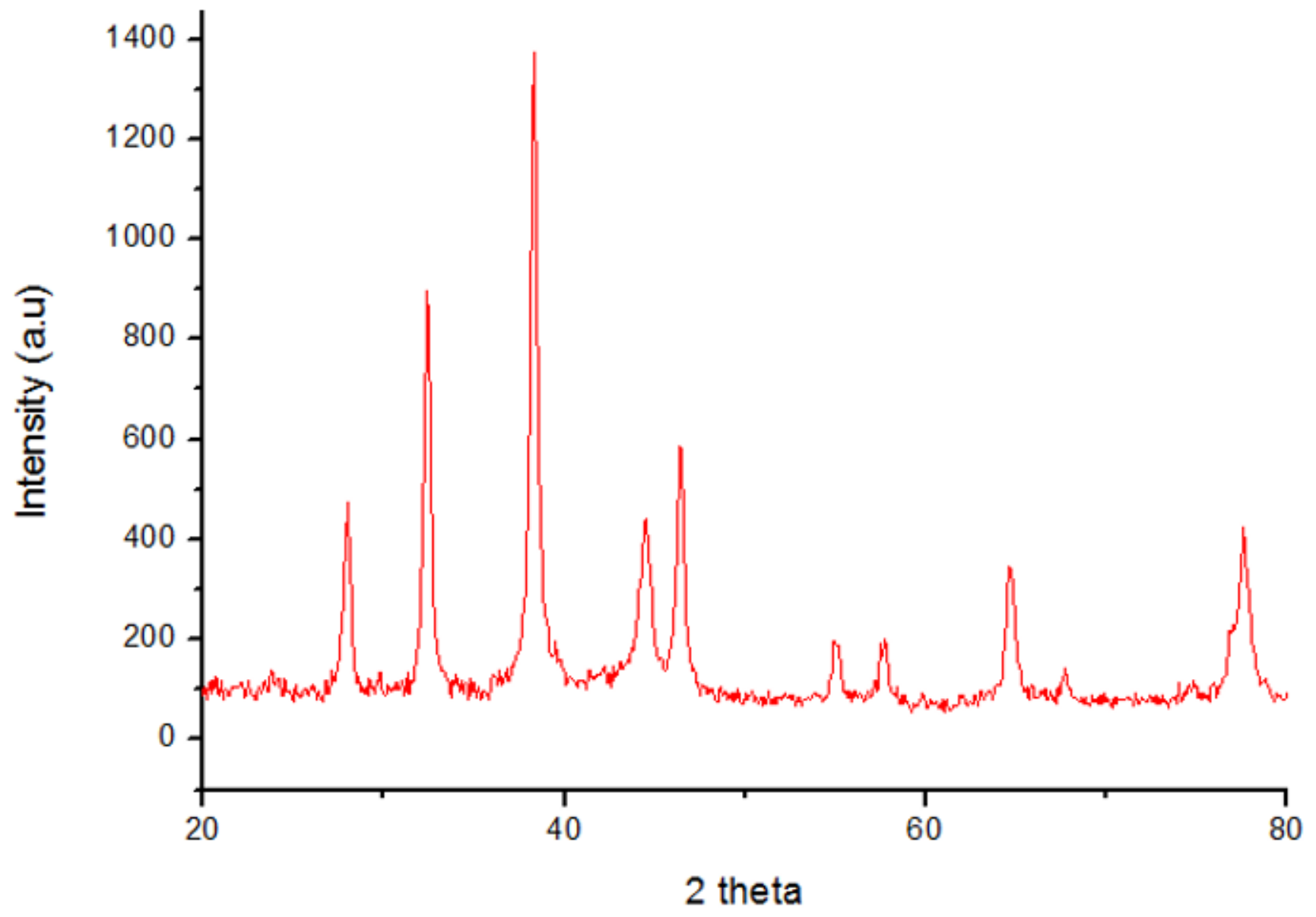

Figure 5

XRD pattern of Ag NPs synthesized from C. subradiata chloroform extract 


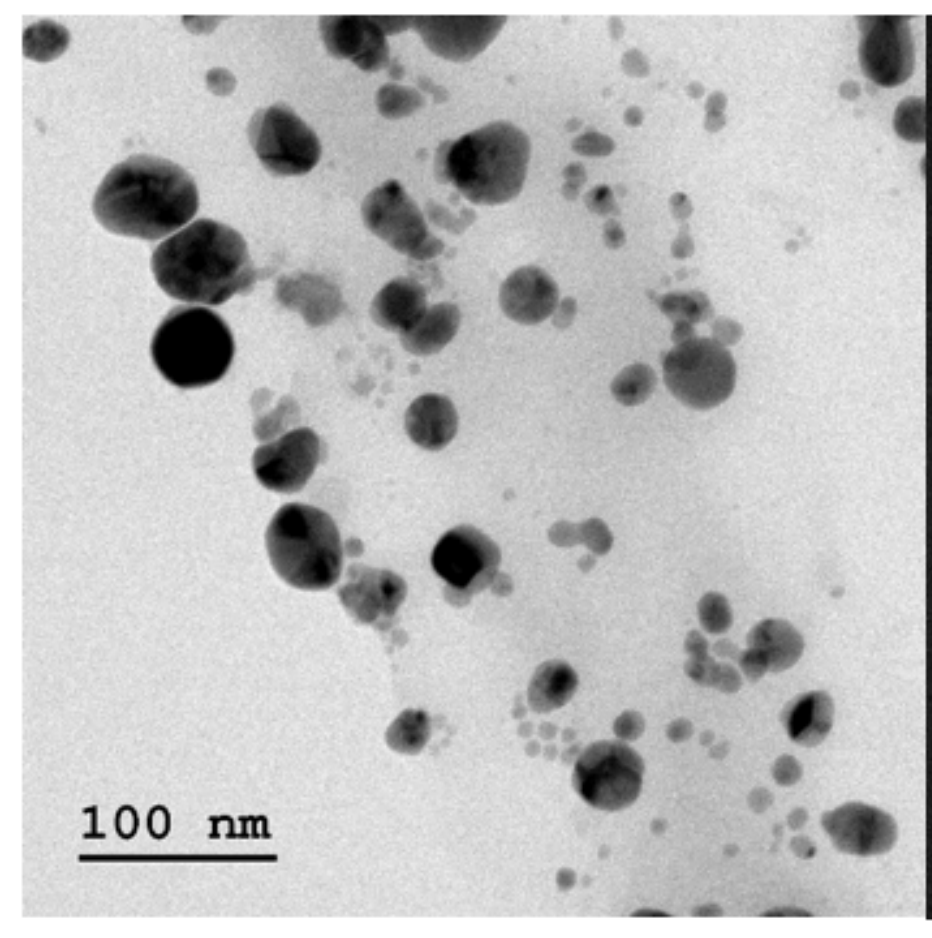

(a)

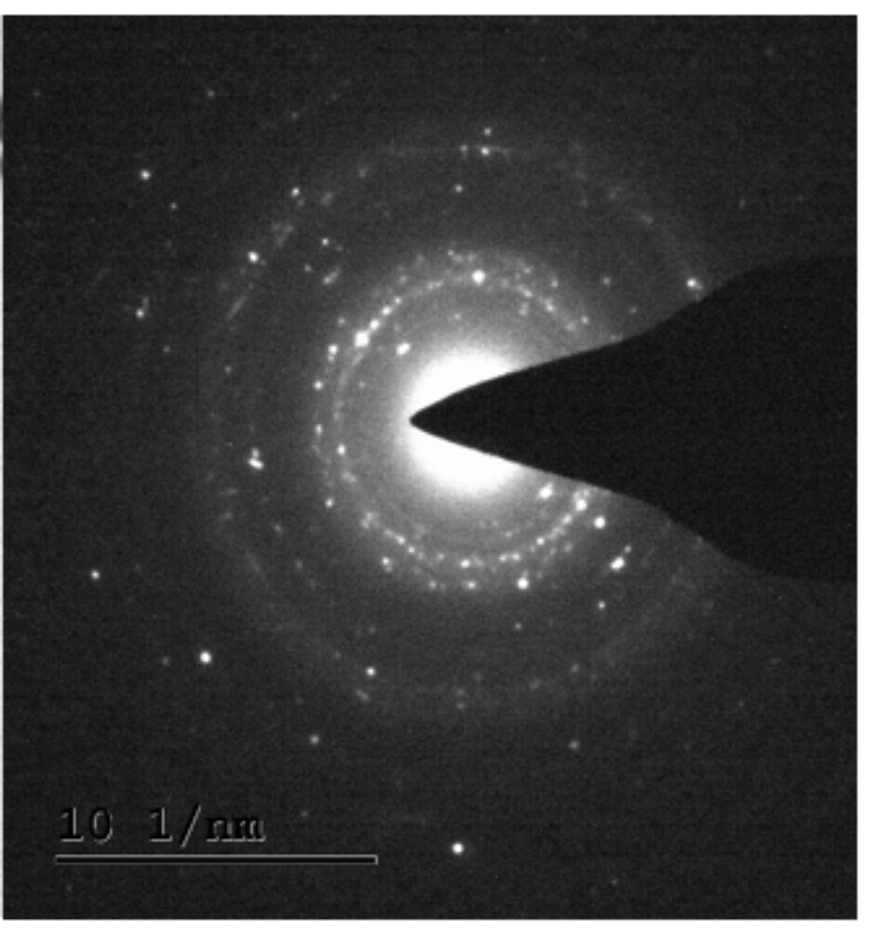

(b)

\section{Figure 6}

(a) TEM micrograph of Ag NPs synthesized from C. subradiata chloroform extract (b) SAED pattern depicting the crystalline structure of Ag NPs 


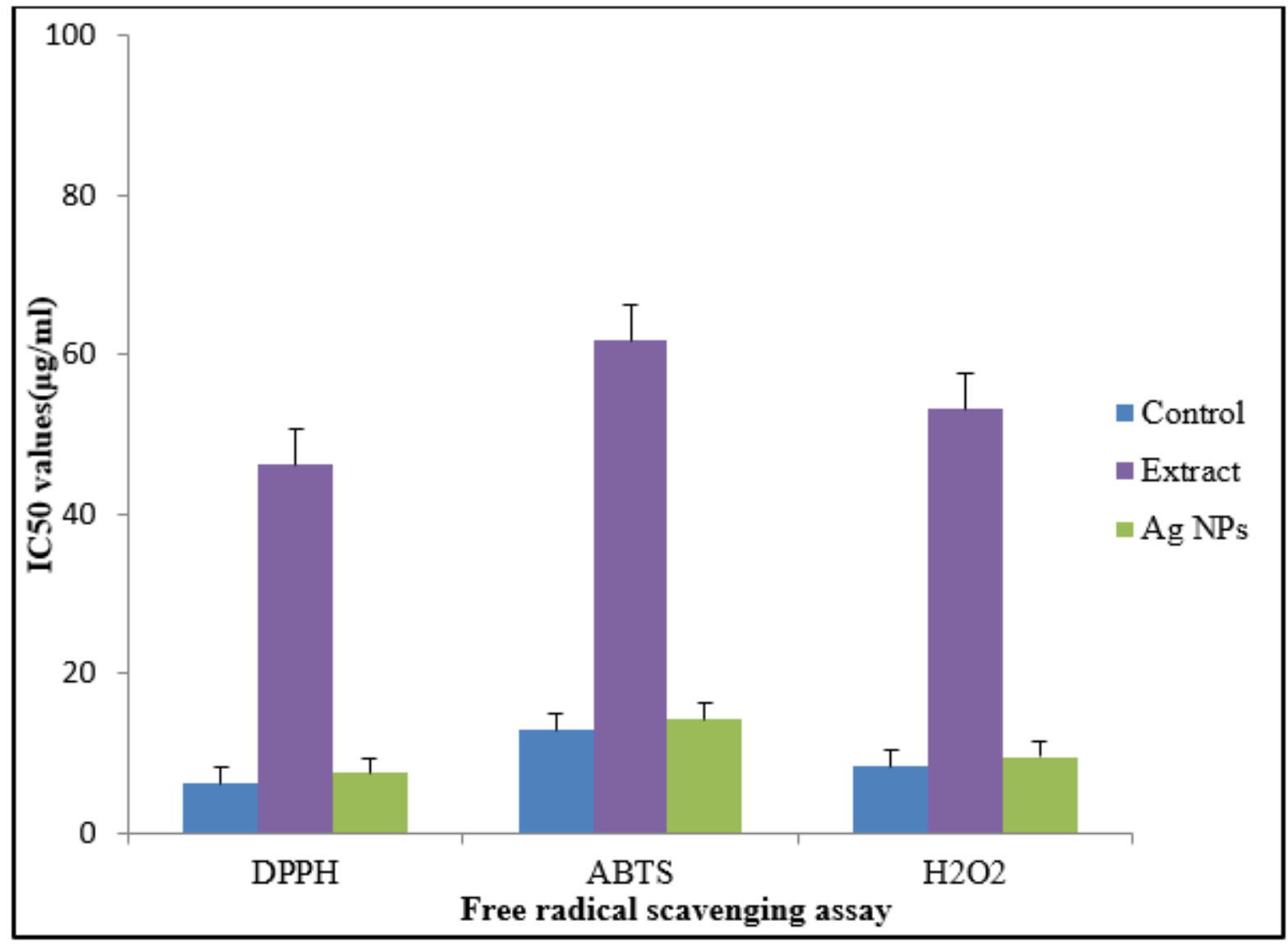

Figure 7

IC50 values of Ascorbic acid, C.subradiata lichen extract and synthesized Ag NPs for free radical scavenging assays 

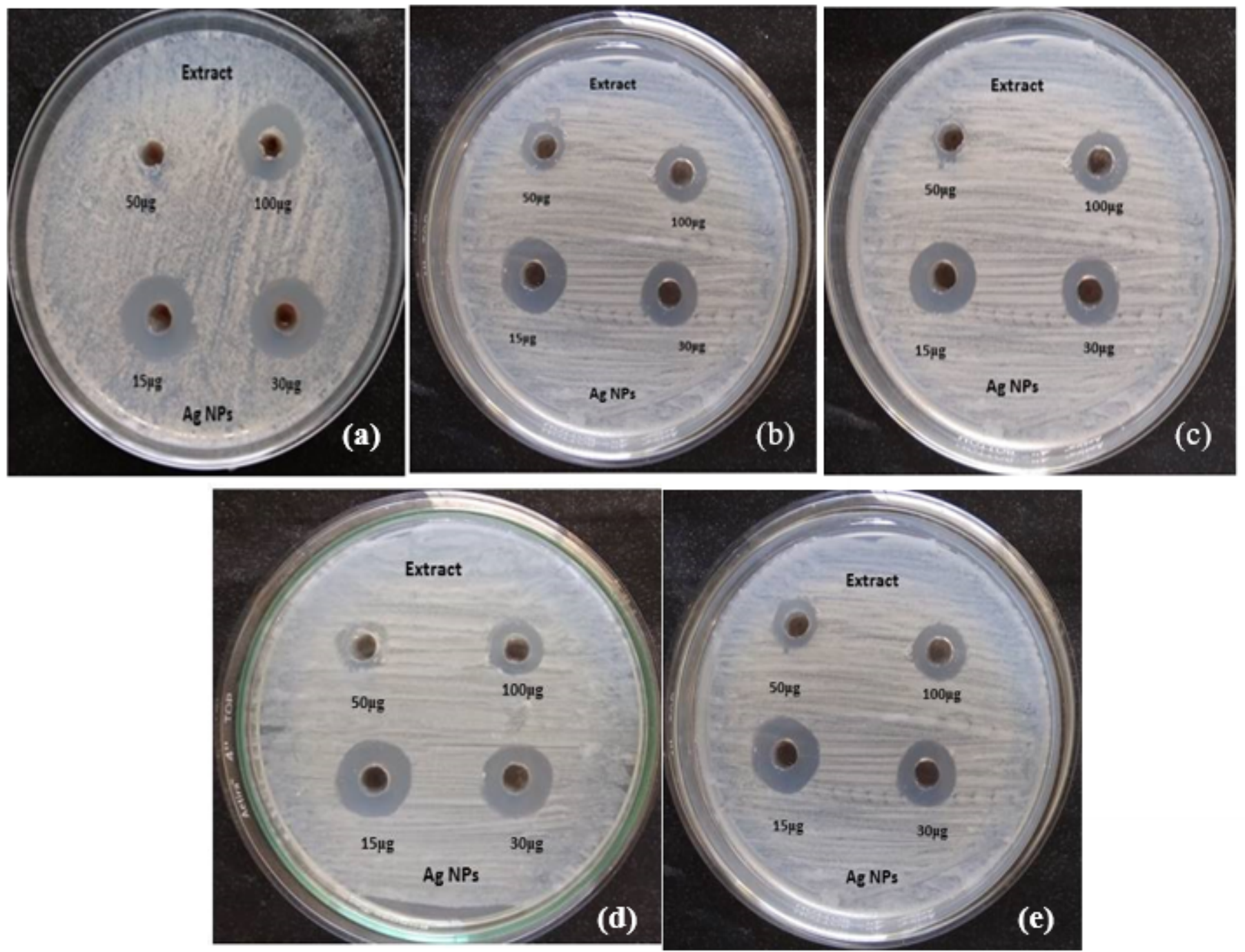

\section{Figure 8}

ZOI of candida strains treated with C. subradiata chloroform extract and Ag NPs (a) C. albicans, (b) C. tropicalis, (c) C. krusei, (d) C. glabrata,(e) C. parapsilosis 


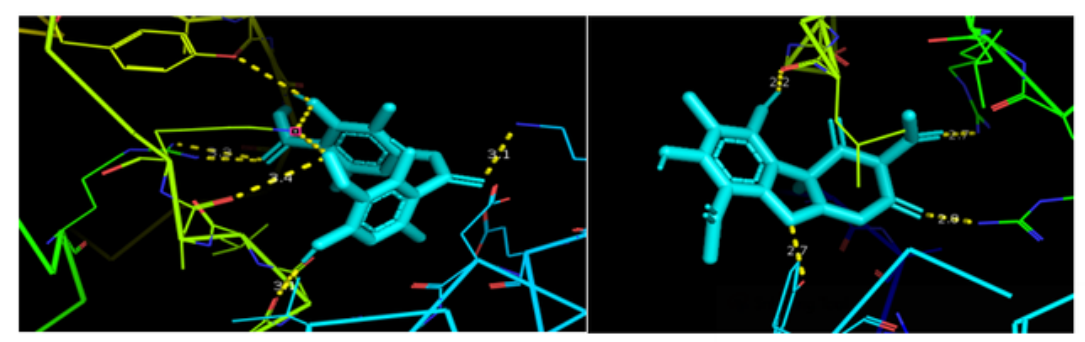

(a)

(b)

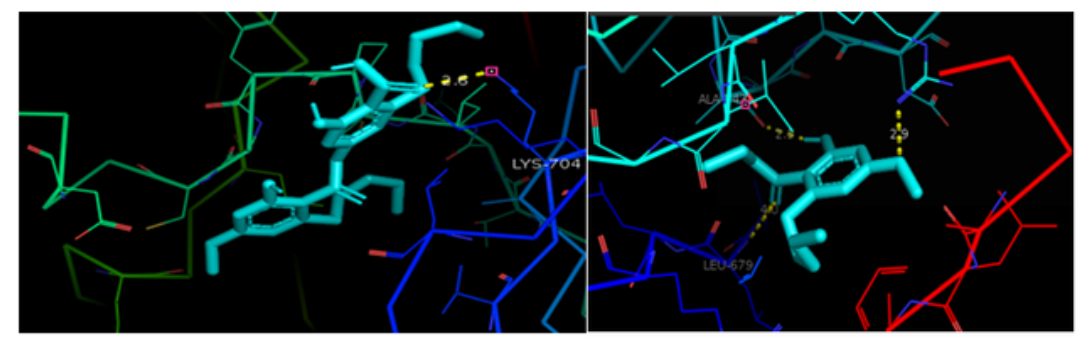

(c)

(d)

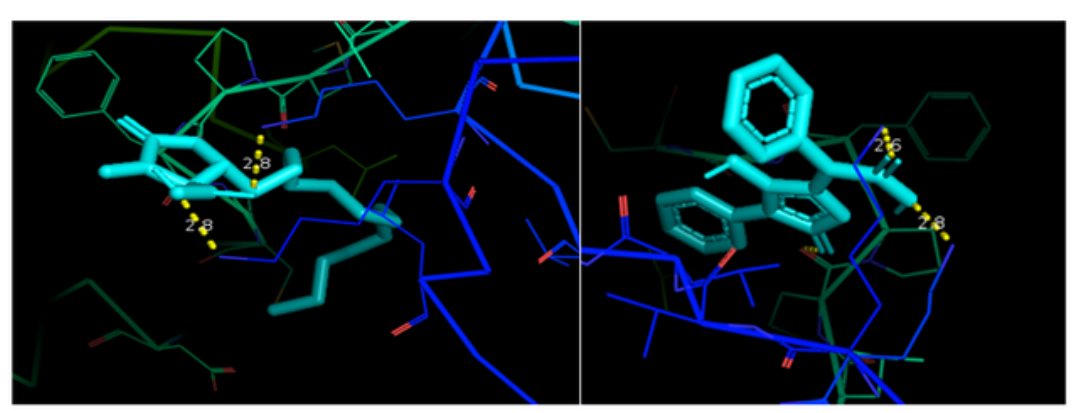

(e)

(f)

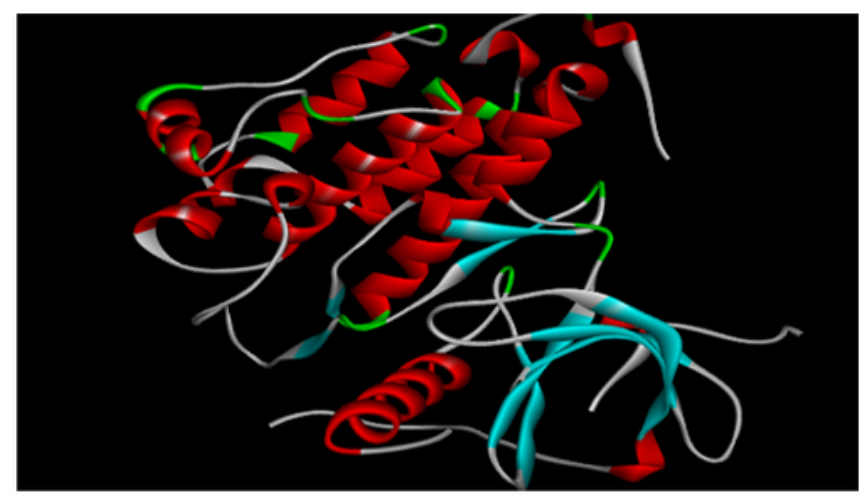

(g)

\section{Figure 9}

Interactions of (a) Atranorin, (b) Usnic acid, (c) Perlatolinic acid, (d) Ethyl-2-hydroxy-4-methoxy-6pentylbenzoate, (e) Protolichesterinic acid, (f) Pulvinic acid with EGFR (g) lung cancer protein studied using Molecular docking approach 


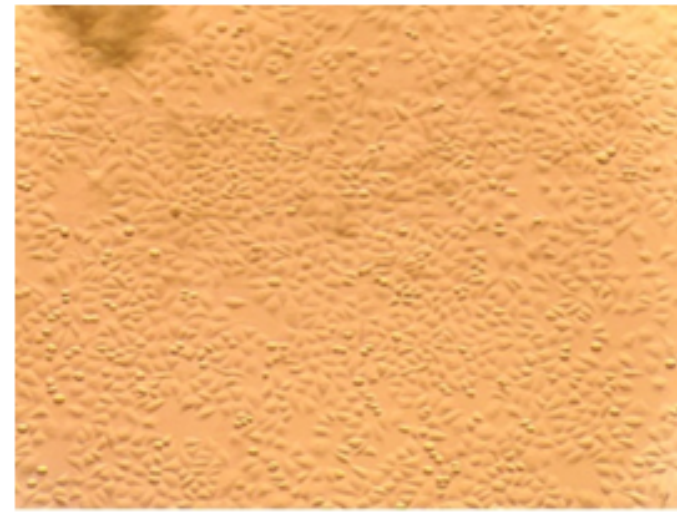

(a)

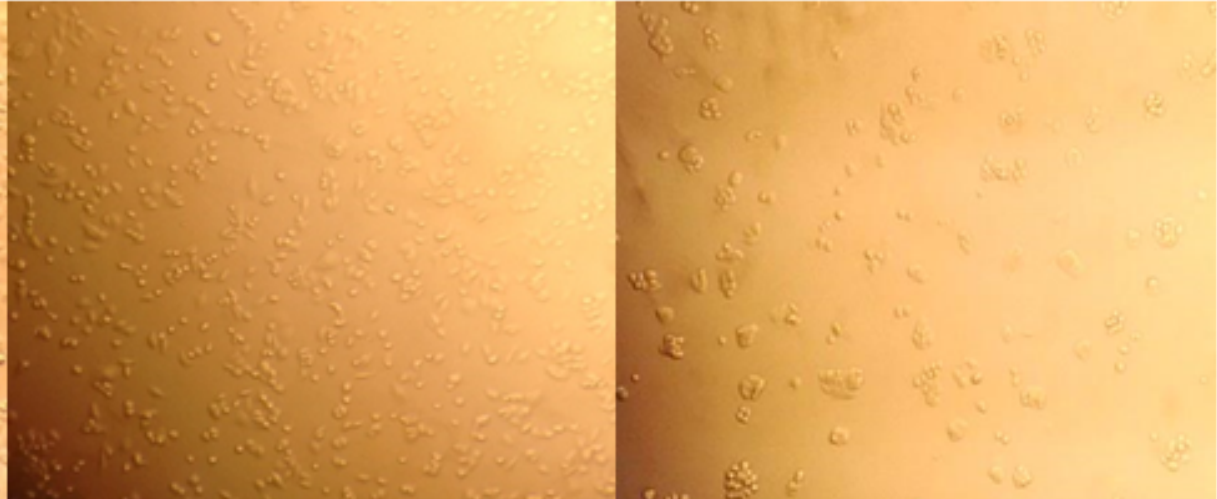

(b)

(c)

\section{Figure 10}

(a) A549 control cells, (b) Cytotoxic effect on A549 cells treated with C.subradiata chloroform extract, (c) Cytotoxic effect on A549 cells treated with Ag NPs 